\title{
THE EFFECT OF USING A MOBILE APPLICATION ON EFL LEARNERS' BELIEFS ABOUT LANGUAGE LEARNING (BALL)
}

\author{
Rebeca Soler Costa \\ Dept. of Educational Sciences, Faculty of Education, University of Zaragoza, rsoler@unizar.es \\ Turgay Han \\ Dept. of English Language and Literature, Faculty of Science and Letters, Ordu University, Turkey, \\ turgayhan@yahoo.com.tr \\ https://doi.org/10.17060/ijodaep.2017.n1.v2.935
}

Fecha de Recepción: 9 Marzo 2017

Fecha de Admisión: 1 Abril 2017

\section{ABSTRACT}

This qualitative case study aimed to examine the effects of using a mobile application (WhatsApp) on on Turkish EFL learners' BALL. This study demonstrates that following 4-week WhatsApp EFL classes changed 40 Turkish EFL learners' BALL. Open-ended questions and a focus group interview were used to collect the data. The findings showed that students' opinions towards using such mobile devices and applications in classrooms are positive and they changed their BALL. It is implicated that such applications can help students to develop positive attitudes toward learning EFL.

Keywords: mobile application, health, qualitative study, education.

\section{INTRODUCTION}

Mobile-assisted language learning (MALL) is one of the widely discussed topics (e.g. Jones, Edwards, \& Reid, 2009; Tsou, Wang, \& Tzeng, 2006). Using mobile devices in learning languages may be effective as they are a big part of our social lives today (Chen \& Kessler, 2013). While some MALL research has focused on general effect/impact view (e.g. Miangah \& Nezarat, 2012; Ono \& Ishihara, 2011) regarding the language skills such as vocabulary (e.g. Ba o lu \&Akdemir, 2010; Lu, 2008; Stockwell, 2010), pronunciation (e.g.Saran, Seferoglu, \&Cagiltay, 2009), reading (Hsu, Hwang, \& Chang, 2013), and grammar (e.g. Baleghizadeh \& Oladrostam, 2010), other studies focused on perception (Al-Fahad, 2009; Hsu, 2013), motivation (Ilter, 2009) and factors (Liu, Han, \& Li, 2010) about MALL.

BALL has been an area of interest for two decades. Horwitz's (1987) 'Beliefs About Language Learning Inventory' (BALLI) that made the topic gain momentum. Beliefs and its cognitive and metacognitive combinations such as motivation, perception, strategy use, and attitudes (Yang, 
1999) have been the primary focus of existing literature. Further, gender (Bernat \& Lloyd, 2007), studying abroad and background (Truitt, 1995).

Available literature has shown that researchers' general attitude towards MALL is positive (Jones, Edwards, and Reid, 2009; Miangah \& Nezarat, 2012; Ono \& Ishihara, 2011; Wang, Shen, Novak, and Pan, 2009). Some MALL studies have focused on vocabulary. In their 2010 study, Ba 0 lu and Akdemir examined the effect of an online vocabulary design and flashcards on the success of vocabulary learning and found that students who used mobile phones had better success and higher motivation. Similarly, Lu (2008) compared paper-based and mobile-assisted (m-assisted) vocabulary learning and found that the m-assisted method had a greater impact on their success. Alemi et al. (2012) and Çavu and brahim, (2009) found that MALL has advantages for vocabulary learning. However, Zhang et al., (2011) pointed out the disadvantages of MALL in vocabulary learning. For example, mobile phones may cause distractions for students, and what was learned via mobile devices may be less permanent for students. Similarly, Hayati et al. (2013) underlined that MALL may drag teachers into a passive role, and this is a negative effect, as teacher interaction plays a more crucial role in students' learning compared to mobile devices.

Other studies investigated the effect of using mobile devices on pronunciation (Saran et al., 2009), reading comprehension (Hsu et al., 2013), grammar (Baleghizadeh \& Oladrostam, 2010). Regarding the BALL studies and mobile devices, to our best knowledge, only Ba aran and Cabaro lu (2014) investigated whether podcast usage via mobile phones has any impact on 187 EFL learners' BALL. BALLI and semi-structured interviews were used to collect the data. The results showed that podcasts had favorable effects on certain types of LL beliefs. To our best knowledge, only a study investigated the use of podcasts via mobile phones on BALL (Ba aran \& Cabaro lu, 2014) but there is no other existing literature examining the relationship between the use of the WhatsApp application in Turkish EFL classes and the students' BALL. Therefore, this study aims to bridge this research gap through examining how EFL students describe their 4-week experiences following WhatsApp classes and if these experiences influence their beliefs related to learning English. The research questions of this study are the following:

How do EFL students describe their 4-week experiences participating in WhatsApp classes?

Do these experiences influence their beliefs related to learning English?

\section{METHODOLOGY}

A case study was chosen in order to more fully understand the changing beliefs of EFL students who attended the WhatsApp classes. The context is EFL students who are taking foundational EFL courses in a Turkish state university. WhatsApp was used for four weeks to examine how the participants' BALL change.

\section{Participants}

The participants were 40 volunteer undergraduate level prep-class students taking English foundation courses in a state university in Turkey. They had 30 hours of English foundation courses per week for an academic year. These students were attending regularly several language skill-based courses in English for 2 months at the time of data collection.

\section{Data collection tools}

First, a background questionnaire was used to collect data about the demography of the participants. Next, five open-ended questions were handed out to participants before the WhatsApp experience to examine what kind of beliefs and understanding students had towards language learning and the usage of mobile devices in language classrooms. Third, WhatsApp, a free mobile applica- 
tion used for instant messaging, was used to do some activities such as making dialogues, picture talking, and writing very short stories. Fourth, after the four-week experience, a focus group interview was used to examine the students' feelings about the use of WhatsApp speaking activities and their anxieties.

\section{Procedure}

Data for this study were collected in several phases. First, 40 volunteer students responded to the background questionnaire and 5 open-ended questions. This data was used to observe their BALL. Second, the participants were informed about the procedure and were told how to proceed. The activities took four weeks, and one activity was done per week. The first task included writing a mini dialogue in pairs about a topic they had learned that day. As they finished writing the dialogue, they were instructed to call their teacher to have a quick look for simple corrections ( 5 mins.). Then, they practiced and recorded it within their WhatsApp group. They listened to their dialogues to see if they were clear and also listened to dialogues (from other student groups). The speaking/recording activity was conducted every other class or even at the end of every class. Mini-dialogues (about 5 lines) were proposed; these took about 10 minutes. 5 minutes were spent creating dialogues, and another 5 minutes were spent practicing and recording.

The following week the students were given the task of writing a mini story. As the students learnt past simple that day, they were instructed to continue a sentence written on the board. Once they finished writing, they were instructed to call their teacher for simple corrections (5 mins). After feedback, students practiced and sent it within their WhatsApp group. They read their stories to see if they were clear and also read the stories from other student groups. The activity was conducted every other class or even at the end of every class. Writing stories (about 5 lines) were proposed; these took about 10 minutes. Five minutes were spent creating the story and another 5 minutes were spent practicing.

The task of the third week was picture talking. The students were supposed to talk about a picture they like. They presented the picture to their teachers and talked about it instantly. After simple corrections, students recorded themselves and sent the recordings with the pictures within their WhatsApp group. They listened to their recordings to see if they were clear and also listened to recordings from other student groups. The speaking/recording activity was conducted every other class or even at the end of every class. Finding pictures was instructed; these took about 10 minutes. 5 minutes were spent talking about the picture and, another 5 minutes were spent practicing and recording. The fourth task was creating a dialogue as they did in the first week, and the procedure was the same.

All the students were supposed to be in the WhatsApp group. They met their WhatsApp groups in class and practiced what they were instructed to do. The activities were shared, so that apart from learning from their own tasks they could also learn from each other.

Finally, a random sub-sample of six students among the participants attended focus group interviews. Semi-structured interview questions were specified and delivered to students after they finished the activities on WhatsApp. They were to discuss about the feelings they experienced during the activities. The interviewees discussed in their native language, Turkish, in order to get accurate and complete results. These interviews were recorded and then transcribed.

\section{Data Analyses}

Qualitative analysis was applied to the study. Using the open coding method (Strauss \& Corbin, 1990), the participants' writings and interviews were read and reread in order to classify the 
responses and label them into groups. The recorded focus group interview was transcribed and translated into English. After reading the transcription several times, the labeling and categorization procedure was completed. In the final step, results of both the writings and the focus group interview were compared. This comparison was interpreted into the findings.

\section{RESULTS}

\section{Pre-course Data Analysis. Open-ended Questions}

Five open-ended questions were posed to participants. The purpose was to learn students' beliefs about mobile devices and language learning before the experiment was conducted so that there could be a comparison of pre and post results of the study.

\section{The idea of using mobile devices in language classrooms}

The first open ended-question asked was about participants' opinions about the usage of mobile devices. Of the 40 participants, 40 people responded to this question, for a total of 49 individual answers. Basic repeated themes symbolizing major opinions were determined and analyzed. The following 4 major themes were identified: a) usefulness, b) indispensability, c) easiness, d) permanence. Table below shows a summary of these answers.

Table 1. Participants' Opinions regarding the idea of using of Mobile Devices in Language Classrooms: Total Number of Responses

\begin{tabular}{ll}
\hline Opinions & Total \\
\hline Usefulness & $\mathbf{3 4}(\mathbf{6 9 \%})$ \\
\hline Indispensability & $\mathbf{4 ( 8 \% )}$ \\
\hline Easiness & $\mathbf{8 ( 1 6 \% )}$ \\
\hline Permanence & $\mathbf{3 ( 6 \% )}$ \\
\hline Total & $\mathbf{4 9 ( 1 0 0 \% )}$ \\
\hline
\end{tabular}

Usefulness is the largest percentage of students' opinions. As Table 1 shows, most of the students think that mobile device usage in language classrooms is useful and helpful. Of the 49 individual answers, 4 of the participants' mentioned the indispensability of the mobile devices. They think these devices are indispensable parts of learning. 8 of students mentioned that such devices ease their learning. 3 of the participants mentioned that when they use mobile devices, what they learn becomes permanent.

The students' belief about learning to speak English through the WhatsApp

The second open-ended question asked was about participants' beliefs and opinions about learning to speak English using WhatsApp. Of the 40 students, 38 of the participants responded to this question, for a total of 38 answers. General attitudes of the respondents were categorized and this categorization is summarized in Table 2.

Table 2. Participants' Attitudes towards Learning to Speak English after WhatsApp Activity.

\begin{tabular}{ll}
\hline Opinions & Total \\
\hline Positive & $\mathbf{3 6}(\mathbf{9 4 \% )}$ \\
\hline Neutral & $\mathbf{2 ( 6 \% )}$ \\
\hline Total & $\mathbf{3 8}(\mathbf{1 0 0 \% )}$ \\
\hline
\end{tabular}


Almost all of the respondents were positive in their answers. They mentioned how effective this activity was, and they replied that they feel more comfortable using WhatsApp. 2 of the participants replied as neutral and they mentioned in their answers that this activity was neither useful nor useless. Interestingly, none of the students were negative towards using WhatsApp to learn English.

The most important skill to learn

The third open-ended question asked was about students' opinions about the skills of English in terms of importance. Of 40 participants, 40 of them responded to this question, for a total of 52 individual answers. The following 7 items were the basic repeated themes of the students' opinions. These items were: a) speaking, b) vocabulary, c) listening, d) all, e) grammar, f) writing, g) reading.

Table 3. Participants' Opinions about the Importance of English Language Skills.

\begin{tabular}{ll}
\hline Skills & Total \\
\hline Speaking & $\mathbf{2 1 ( 4 0 \% )}$ \\
\hline Vocabulary & $\mathbf{9 ( 1 7 \% )}$ \\
\hline Listening & $\mathbf{7 ( 1 3 \% )}$ \\
\hline All & $\mathbf{6 ( 1 1 \% )}$ \\
\hline Grammar & $\mathbf{4 ( 7 \% )}$ \\
\hline Writing & $\mathbf{3 ( 5 \% )}$ \\
\hline Reading & $\mathbf{2 ( 4 \% )}$ \\
\hline Total & $\mathbf{5 2 ( 1 0 0 \% )}$ \\
\hline
\end{tabular}

Answers for the question of importance of English language skills were mainly in 7 groups. Most of the answers showed that speaking was in a higher place compared to other skills. Nearly half of the participants thought that speaking is the utmost important skill. Interestingly, the students reported that they thought the other skills (e.g. vocabulary, listening, grammar, writing, and reading) were all of equal importance. The second most important skill appeared to be vocabulary with 9 respondents which was followed by listening with 7 people. 6 of the respondents said that none of the skills are more important than others; they are all important. 4 participants determined that grammar was the most important, while 3 participants chose writing, and 2 participants chose reading.

\section{The easier language skills}

The fourth open-ended question asked was about the skills of English in terms of easiness. All of the 40 participants responded to the question, for a total of 43 answers. The following 7 items were the basic repeated themes. These items were: a) reading, b) writing, c) listening, d) speaking, e) vocabulary, f) grammar, g) pronunciation.

Table 4. Participants' Opinions about the Easiness of English Language Skills

\begin{tabular}{ll}
\hline Skills & Total \\
\hline Reading & $\mathbf{1 8 ( 4 2 \% )}$ \\
\hline Writing & $\mathbf{1 0 ( 2 3 \% )}$ \\
\hline Listening & $\mathbf{7 ( 1 6 \% )}$ \\
\hline Speaking & $\mathbf{3 ( 7 \% )}$ \\
\hline Vocabulary & $\mathbf{3 ( 7 \% )}$ \\
\hline Grammar & $\mathbf{1 ( 2 \% )}$ \\
\hline Pronunciation & $\mathbf{1 ( 2 \% )}$ \\
\hline Total & $\mathbf{4 3 ( 1 0 0 \% )}$ \\
\hline
\end{tabular}


Students' answers show that reading is regarded as the easiest skill. As Table 4 shows, there were 10 responses indicating that writing is the easiest skill to learn while 7 of the responses indicated listening is the easiest one. Other skills mentioned in the study are speaking and vocabulary; each of these were deemed as the most important skill in 3 responses. Grammar and pronunciation skills were deemed most important by one response each.

How to learn language skills better?

The fifth and last open ended question was to learn the students' opinions about how language skills can be learnt better. All of the participants answered the question and a total of 41 responses were determined in terms of themes symbolizing major opinions. The following are the responses grouped as five keywords: a) practice, b) social entertainment) speaking with natives, d) pleased, and e) vocabulary.

Table 5. Participants' Opinions about How Language Skills Can Be Learnt Better.

\begin{tabular}{ll}
\hline Keywords & Total \\
\hline Practice & $\mathbf{1 6 ( 3 9 \% )}$ \\
\hline Social entertainment & $\mathbf{1 1 ( 2 7 \% )}$ \\
\hline Speaking with natives & $\mathbf{9 ( 2 2 \% )}$ \\
\hline Pleased & $\mathbf{4 ( 9 \% )}$ \\
\hline Vocabulary & $\mathbf{1 ( 2 \% )}$ \\
\hline Total & $\mathbf{4 1 ( 1 0 0 \% )}$ \\
\hline
\end{tabular}

As the fifth table shows, 16 of the responses are favoring practice. These students think that studying regularly what was taught, practicing by repeating that day's subjects and acquiring competence about the skills are necessary. Learning mostly depends on their own practice. Interestingly, 11 of the responses are favoring social entertainment tools, such as watching movies in the target language, listening songs in English, and reading books, newspapers, to learn English skills. These participants think that these activities are the ones where they can practice most of the skills at the same time. 9 responses, on the other hand, mention that the best way to acquire such skills is either to visit an English-speaking country or to speak with native speakers of English. 4 of the respondents are satisfied with the current methods used to teach them English while 1 person thinks learning skills depends on learning more words.

Post-course Data Analysis

What are your opinions about the WhatsApp activities?

The results of interview discussions indicated that students liked the idea of using WhatsApp in classrooms. Moreover, the students mentioned different types of benefits of using WhatsApp activities. According to the participants, the main benefits of using WhatsApp were that it was helpful both for reducing anxiety and for pronunciation and speaking, and what was learnt was more permanent.

"Well, it was a helpful activity. I did not feel anxiety when we sent our voice recordings. It was a good activity for me." [Student $A$ ]

"It was very useful activity for our class but I do not think it was helpful for anxiety..." [Student B]

"It was pretty good both for me and for my friends. I could overcome my anxiety by writing and recording my voice. I think it is helpful." [Student C] 
“... I could strengthen what I learnt. Making sentences were pretty helpful so I can say that it was very useful..." [Student D]

"When we were recording our voice, I and Batu practiced the pronunciations several times to be able to pronounce well and send the recordings each other. We sent the best recording to the group. With the help of this I improved my pronunciation which was more than bad at the beginning." [Student E]

"Writing on a piece of paper and reading from it is not something helps, but when we made this on WhatsApp, like we did with picture talking..." [Student F]

\section{How did WhatsApp activities affect your language learning process?}

The second question of the interview aimed to identify the effects of the WhatsApp activity on participants' language learning process. The results showed that the activity helped students in several ways such as acquiring new vocabulary, practicing pronunciation, retaining learned material, and reducing anxiety. The participants were affected positively by WhatsApp. Below are the answers students gave.

"It helped me in terms of vocabulary..." [Student B]

"Generally I agree with Fulya. It helped me to learn new words. I can add pronunciation to this as well." [Student A]

"It was very good for speaking..." [Student C]

"Everybody shared their own work here. As all of us are in the group, we all paid attention, and this make us learn better... We paid extra attention because of this and doing this affected us positively." [Student D]

"... This helped me in terms of pronunciation and speaking... Normally, any student may answer a question that you want to answer. However, we can show ourselves in WhatsApp." [Student E]

"Here is the thing. I do not study at home. It is enough for me to learn in the classroom but I take notes on my phone and I learnt to do this thanks to WhatsApp study..." [Student F]

What do you think about learning a foreign language using WhatsApp after the experience?

The question aiming to learn interviewees' opinions about learning a foreign language via WhatsApp was mostly positive. The answers had repeating qualities about what the participants mentioned in their former statements. One answer, on the other hand, stood out among other responses as it was favoring the importance of the topic and the way of learning via WhatsApp. The answer was:

"Actually, topic that we are supposed to write or speak on is important..." [Student B]

\section{How should learning a foreign language via WhatsApp be?}

This next question was to learn the opinions of the participants about the way WhatsApp can be used for language learning. All the responses pointed out the same skill: speaking. Participants generally felt that writing is an achievable skill, and they can do it somehow. However, they feel like they need to use this application for two reasons: one is that speaking is really important, and the other reason is that they believe they can speak via this application.

"Well, these kinds of exercises would be very good if we could do in WhatsApp" [Student E]

"I think we should use this application for speaking rather than writing..." [Student F]

"I agree. We can practice writing at school as well" [Student B] 
"We cannot because sometimes we use Google Translate when we are unable to write". [Student F]

"I think we should use this for speaking because I think we can write anyway" [Student D] "Exactly". [Student A]

"Everybody can achieve writing somehow but speaking is a problem for almost all of us" [Student B]

\section{What skills do you think WhatsApp activities affected most?}

The last question of the interview was to learn students' opinions about the skills WhatsApp affected. The answers did not vary as all of the participants of the focus group interview identified the same skill: speaking.

"Speaking" [All Students]

\section{DISCUSSION AND CONCLUSIONS}

The results indicated that almost all of the participants believed that using mobile devices would be useful for learning English. Some of the participants even thought that such devices are really necessary tools. Al-Fahad (2009) also stated that mobile device usage in language learning is a good support for students and they are useful and rapidly developing tools for language classes. This result also coincides with Hsu et al.'s (2013) study, which confirmed the usefulness of the MALL with ninety percent of the study participants.

The post-course data (e.g. focus group interview) revealed that using WhatsApp did not make any changes on students' BALL. However, it had a positive effect, which confirmed students' beliefs about using a mobile device in language classrooms. Students pointed out that using mobile device helped them reduce their anxiety and improve their pronunciation and speaking skills. Moreover, as participants stated, what they learnt via WhatsApp was easier to remember later on. This result can be considered as interesting because it is either unique or one of the most scarcely mentioned results in the existing literature.

Both the replies to the open-ended questions and focus-group interviews showed students had a positive attitude towards using such devices in language classrooms. In the study Al-Fahad (2009) conducted, it was demonstrated that students strongly agreed that learning via mobile devices can be very effective. Therefore, their attitude towards learning via mobile devices was positive. Hsu (2013), on the other hand, showed that usage of mobile devices motivates some students, but for some others, such usage keeps being new and difficult. Further, the interview data showed students could maintain their positive opinions towards MALL if the method with which and the topic they are instructed is interesting. It should be mentioned that the study did not change students' beliefs about using mobile devices in language classrooms but confirmed what students thought. As KukulskaHulme and Shield (2008) emphasize, using mobile devices in many aspects of life is a rapidly growing trend, and educators should pay attention to the effects on learning while incorporating this trend in language teaching.

Next, the data analyses showed that language skills could be learnt better via practice and social entertainment. This study combined practice and social entertainment. These results are congruent with many tenets of sociolinguistics. Sociolinguistic theory argues that there is a link between social interaction and language learning (Halliday, 1978; Lantolf et al., 2014; Peirce, 1995). Finally, after the experience the expressed that speaking is the most important skill while reading is the easiest one to learn. This study is limited in the following ways: number of study participants, duration of application and data collection tools. Further research could investigate this issue by think-aloud protocols. 


\section{REFERENCES}

Al-Fahad, F. N. (2009). Students' Attitudes and Perceptions towards the Effectiveness of Mobile Learning in King Saud University, Saudi Arabia. ERIC Online Submission, 8(2). Retrieved from http://eric.ed.gov/?id=ED505940 on 29.11.2015

Alemi, M., Sarab, M. R. A., \&Lari, Z. (2012). Successful learning of academic word list via MALL: Mobile assisted language learning. International Education Studies, 5(6), p99. http://dx.doi.org/10.5539/ies.v5n6p99

Baleghizadeh, S., \& Oladrostam, E. (2010). The effect of mobile assisted language learning (MALL) on grammatical accuracy of EFL students. MEXTESOL Journal, 34(2), 1-10. Retrieved from http://www.mextesol.net/journal/index.php?page=journal\&id_article=50 on 29.11.2015

Basaran, S., \& Cabaroglu, N. (2014).Language Learning Podcasts and Learners' Belief Change.TESL-EJ, 17(4), n4 retrieved from http://eric.ed.gov/?id=EJ1024978 on 30.11.2015

Ba o lu, E. B., \&Akdemir, O. (2010). A Comparison of Undergraduate Students' English Vocabulary Learning: Using Mobile Phones and Flash Cards. Turkish Online Journal of Educational Technology-TOJET, 9(3), 1-7. Retrieved from http://files.eric.ed.gov/fulltext/EJ898010.pdf on 29.11.2015

Bernat, E., \& Lloyd, R. (2007). Exploring the gender effect on EFL learners' beliefs about language learning. Australian Journal of Educational \& Developmental Psychology. Vol 7, pp 79-91.

Best, J. W., \& Khan, J. V.(2006). Research in Education, Tenth Edition. Boston. Pearson.

Cavus, N., \& Ibrahim, D. (2009). m Learning: An experiment in using SMS to support learning new English language words. British Journal of Educational Technology, 40(1), 78-91. http://dx.doi.org/10.1111/j.1467-8535.2007.00801.x

Chen, X. B., \& Kessler, G. (2013). Action Research Tablets for Informal Language Learning: Student Usage and Attitudes . Language, Learning \& Technology, 17(1). Retrieved from http://hdl.handle.net/10125/24503 on 28.12.2015

Corbin, J. M., \& Strauss, A. (1990). Grounded theory research: Procedures, canons, and evaluative criteria. Qualitative sociology, 13(1), 3-21. Retrieved from http://link.springer.com/article/10.1007/BF00988593\#page-1 on 01.01.2016

Hayati, A., Jalilifar, A., \&Mashhadi, A. (2013).Using Short Message Service (SMS) to teach English idioms to EFL students.British Journal of Educational Technology, 44(1), 66-81. http://dx.doi.org/10.1111/j.1467-8535.2011.01260.x

Halliday, M. A. K. (1978). Language as social semiotic (p. 136). Arnold: London.

Hsu, C. K., Hwang, G. J., \& Chang, C. K. (2013).A personalized recommendation-based mobile learning approach to improving the reading performance of EFL students.Computers\& Education, 63, 327-336. http://dx.doi.org/10.1016/j.compedu.2012.12.004

Hsu, L. (2013). English as a foreign language learners' perception of mobile assisted language learning: a cross-national study. Computer Assisted Language Learning, 26(3), 197-213. http://dx.doi.org/10.1080/09588221.2011.649485

Jones, G., Edwards, G., \& Reid, A. (2009). How Can Mobile SMS Communication Support and Enhance a First Year Undergraduate Learning Environment? ALT-J: Research in Learning Technology, 17(3), 201-218. http://dx.doi.org/10.1080/09687760903247625

Kukulska-Hulme, A., \& Shield, L. (2008). An overview of mobile assisted language learning: From content delivery to supported collaboration and interaction. ReCALL, 20(03), 271-289.

Kuntz, P. S. (1996). Beliefs about language learning: The Horwitz model. HEA Title VI African Studies Centers. Madison, WI: University of Wisconsin, Department of Curriculum and Instruction. ERIC Document Reproduction Service. Retrieved from http://eric.ed.gov/?id=ED397649 on 27.11.2015 
Lantolf, J. P., Thorne, S. L., \& Poehner, M. E. (2014). 11 Sociocultural Theory and Second Language Development. Theories in Second Language Acquisition: An Introduction, 152.

Liu, Y., Han, S., \& Li, H. (2010). Understanding the factors driving m-learning adoption: a literature review.Campus-Wide Information Systems, 27(4), 210-226. http://dx.doi.org/10.1108/ 10650741011073761

Lu, M. (2008). Effectiveness of vocabulary learning via mobile phone. Journal of Computer Assisted Learning, 24(6), 515-525. Doi:10.1111/j.1365-2729.2008.00289.x Miangah, T. M., \&Nezarat, A. (2012).Mobile-assisted language learning. International Journal of Distributed and Parallel Systems, 3(1), 309-319. http://dx.doi.org/10.5121/ijdps.2012.3126

Ono, Y., \& Ishihara, M. (2011). The mobile-based training in an EFL classroom. In Proceedings of the 19th International Conference on Computers in Education (pp. 422-424). Retrieved from http://www.nectec.or.th/icce2011/program/proceedings/pdf/C4_P1_77.pdf on 29.11.2015

Peirce, B. N. (1995). Social identity, investment, and language learning. TESOL quarterly, 9-31. Retrieved from http://203.72.145.166/tesol/tqd_2008/VOL_29_1.pdf\#page=8 on 01.01.2016

Saran, M., Seferoglu, G., \& Cagiltay, K. (2009). Mobile assisted language learning: English pronunciation at learners' fingertips. Eurasian Journal of Educational Research, 34(1), 97-114. Retrieved from http://94.73.145.182/0DOWNLOAD/pdfler/tr/902903948.pdf on 29.11.2015

Truitt, S. N. (1995). Beliefs about Language Learning: A Study of Korean University Students Learning English. Texas Papers in Foreign Language Education, 2(1), n1. Retrieved from http://eric.ed.gov/?id=ED416703 on 31.11.2015

Tsou, W., Wang, W., \&Tzeng, Y. (2006).Applying a multimedia storytelling website in foreign language learning. Computers\& Education, 47(1), 17-28.http://dx.doi.org/10.1016/j.compedu.2004.08.013

Vibulphol, J. (2004). Beliefs about language learning and teaching approaches of pre-service EFL teachers in Thailand (Doctoral dissertation, Oklahoma State University). Retrieved from http://digital.library.okstate.edu/etd/umi-okstate-1041.pdf on 25.11.2015

Wang, M., Shen, R., Novak, D., \& Pan, X. (2009). The impact of mobile learning on students' learning behaviors and performance: Report from a large blended classroom. British Journal of Educational Technology, 40(4), 673-695. http://dx.doi.org/10.1111/j.1467-8535.2008.00846.x

WhatsApp Official Webpage.https://www.whatsapp.com/?l=en retrieved on 29.11.2015

Yang, N. D. (1999). The relationship between EFL learners' beliefs and learning strategy use. System, 27(4), 515-535. doi:10.1016/S0346-251X(99)00048-2

Zhang, H., Song, W., \& Burston, J. (2011). Reexamining the Effectiveness of Vocabulary Learning via Mobile Phones. Turkish Online Journal of Educational Technology-TOJET, 10(3), 203-214. Retrieved on 29.11.2015 from http://files.eric.ed.gov/fulltext/EJ944968.pdf 